\title{
Decentralization of Leprosy Control Actions in the Micro-Region of Almenara, State of Minas Gerais ${ }^{1}$
}

\author{
Fernanda Moura Lanza² \\ Francisco Carlos Félix Lana ${ }^{3}$
}

This study analyzes the decentralization process of Leprosy control actions for Family Health Strategy units in the cities of the Almenara micro-region, in the state of Minas Gerais, Brazil. This qualitative research, based on the concept "Technological Organization of Work", was carried out in nine municipalities. Semi-structured interviews and document research were used for data collection. Forty-five interviews with care providers and health managers were conducted. The data collection took place between November 2007 and February 2008. Content Analysis was utilized to study the data and results indicate that the cities present different levels of decentralization and that the process was determined based on local specifications and on the engagement of care providers and health managers. Several cities kept a reference team to provide support to primary health care. The conclusion is that the decentralization process is a strategy that proves to be useful in facing Leprosy in the micro-region.

Descriptors: Decentralization; Primary Health Care; Leprosy/Prevention \& Control.

\footnotetext{
${ }^{1}$ Paper extracted from Master's Dissertation "Tecnologia do Processo de Trabalho em Hanseníase: Análise das Ações de Controle na Microrregião de Almenara, Minas Gerais" presented to Escola de Enfermagem, Universidade Federal de Minas Gerais, MG, Brazil. Supported by CNPq, process \# 40.0785/2005-6.

2 RN, Doctoral Student, Programa de Pós-Graduação em Enfermagem, Escola de Enfermagem, Universidade Federal de Minas Gerais, MG, Brazil. E-mail: fmlanza@yahoo.com.br.

${ }^{3}$ RN, Ph.D. in Nursing, Associate Professor, Escola de Enfermagem, Universidade Federal de Minas Gerais, MG, Brazil. E-mail: xicolana@enf.ufmg.br.
}

Corresponding Author: Fernanda Moura Lanza Universidade Federal de Minas Gerais. Escola de Enfermagem Av. Alfredo Balena, 190, sala 402 Bairro Santa Efigênia CEP: 30130-100 Belo Horizonte, MG, Brasil E-mail: fmlanza@yahoo.com.br 


\section{Descentralização das ações de controle da hanseníase na microrregião de Almenara, Minas Gerais}

O estudo teve como objetivo analisar o processo de descentralização das ações de controle da hanseníase, para as unidades da Estratégia de Saúde da Família, em municípios da microrregião de Almenara, Minas Gerais. Esta é uma pesquisa qualitativa, fundamentada no conceito de Organização Tecnológica do Trabalho, realizada em nove municípios. Como técnicas para a coleta de dados foram utilizadas a entrevista semiestruturada e a pesquisa documental. Foram realizadas 45 entrevistas com gestores e profissionais de saúde. A coleta de dados ocorreu entre novembro 2007 e fevereiro 2008. Para tratamento e análise dos dados, foi utilizada a análise de conteúdo. Os resultados apontam que os municípios se encontram em diferentes estágios de descentralização e que esse processo foi determinado pela especificidade local e pelo engajamento dos gestores e dos profissionais de saúde. Vários municípios mantiveram uma equipe de referência para dar apoio à atenção básica. Conclui-se que o processo de descentralização é estratégia capaz de enfrentar a endemia hansênica na microrregião.

Descritores: Descentralização; Atenção Primária à Saúde; Hanseníase/Prevenção \& Controle.

\section{Descentralización de las acciones de control de la lepra en la microrregión de Almenara, Minas Gerais}

El estudio tuvo como objetivo analizar el proceso de descentralización de las acciones de control de la lepra para las unidades de Estrategia de la Salud de la Familia en municipios de la microrregión de Almenara, Minas Gerais. Se llevó a cabo una investigación cualitativa en nueve municipios, basada en el concepto de "Organización Tecnológica del Trabajo". Se emplearon como técnicas para hacer la recolección de datos la entrevista semiestructurada y la investigación documental. Se realizaron 45 entrevistas con administradores y profesionales de la salud. Los datos fueron recolectados entre noviembre de 2007 y febrero de 2008. Para tratamiento y análisis de los datos se utilizó el Análisis de Contenido. Los resultados apuntan que los municipios se encuentran en diferentes períodos de descentralización y que ese proceso fue determinado por la especificidad local y por el compromiso de los administradores y de los profesionales de la salud. Se concluyó que el proceso de descentralización es una estrategia capaz de enfrentar la endemia en la microrregión.

Descriptores: Descentralización; Atención Primaria de Salud; Lepra/Prevención \& Control.

\section{Introduction}

Leprosy is still a public health problem in Brazil. In World Health Organization (WHO) statistics for 2008, the country ranks second in absolute numbers of new cases detected $(38,914)$, with $52.4 \%$ of these cases being diagnosed as multibacillary forms; $5.9 \%$ with level II physical disability and $7.0 \%$ in people younger than 15 years $^{(1)}$.

Spatial occupation patterns strongly influence leprosy, with unequal distribution and concentration in the poorest locations ${ }^{(2-3)}$. The Vale do Jequitinhonha the region with the worst socioeconomic indicators in the State of Minas Gerais, fits into this profile. The region comprises five micro-regions that have displayed leprosy prevention and control problems. Local health services may not be capable of capturing all existing cases in the region(4) and the Almenara micro-region includes cities that are considered priorities to control this endemic disease in Minas Gerais. Data for 2008 reveal a 
prevalence rate of 47.8 cases/ 10,000 inhabitants and a detection rate of 49.4/ 100,000 inhabitants in this microregion. Out of 90 new cases, 53.3\% were diagnosed with multibacillary clinical forms and $2.2 \%$ with level II physical disability ${ }^{(5)}$.

The disease's epidemiological behavior in this micro-region - predominance of multibacillary clinical forms and high percentages of diagnosed cases already displaying physical disabilities - suggests that health services are facing difficulties to control the disease(6). The key principle of leprosy control is morbidity control, i.e. timely detection of new cases; treatment with chemotherapy (WHO MDT regimens); prevention of disabilities and rehabilitation ${ }^{(7)}$. Therefore, it should be guaranteed that disease control activities are part of Primary Health Care services.

In Brazil, the current primary health care scenario is based on the Family Health Strategy (FHS), which plays a fundamental role in the reorientation of the care model and in the consolidation of SUS (Sistema Único de Saúde - Unified Health System) guidelines, thus contributing to the universalization of health service access and to care decentralization. The publication of NOAS 2001 was essential for health care decentralization purposes and defined the elimination of leprosy as one of the strategic activity areas for primary care services( ${ }^{(8)}$.

Thus, leprosy prevention and control actions have been decentralized to FHS units. Multiprofessional teams at these units work with the health surveillance concept. Their practices aim to solve the most frequent and relevant health problems within their territory. "The main aspect that has facilitated the integration of leprosy control actions into Primary Health Care is undoubtedly the establishment of the Family Health Program Strategy, which also approximated leprosy patients to the necessary care"(9).

The successful integration of disease control actions into Primary Health Care can be assessed based on the improvement of some epidemiological indicators, such as the reduction of cases diagnosed with physical disabilities; reduction of the percentage of cases diagnosed in people younger than 15 years; decrease in the proportion of multibacillary cases and increase in cure rates ${ }^{(10)}$. Thus, cities in the Almenara macro-region face difficulties to integrate leprosy actions into Primary Health Care ${ }^{(6)}$

In view of the epidemiological importance of leprosy in this micro-region and the lack of research on the decentralization of its control actions, the goal of this paper was to analyze the decentralization process of leprosy control actions (LCA) to Family Health Strategy units in cities from the Almenara micro-region in Minas Gerais.

\section{Method}

This qualitative research was based on the concept of "Technological Organization of Work", developed in the health $\operatorname{area}^{(11)}$. This theoretical-methodological option was chosen because it can capture the reality of different scenarios and subjects involved in leprosy care, entailing some particularities of this practice as moments of a broader totality and its historically determined context.

The research scenario comprised nine cities from the Almenara micro-region, located in the Vale do Jequitinhonha, State of Minas Gerais. The cities that participated in the research were: Almenara, Jacinto, Jequitinhonha, Jordânia, Monte Formoso, Palmópolis, Rubim, Santa Maria do Salto and Salto da Divisa.

Data were collected at the Primary Health Care services working with leprosy in response to routine care demands. In each city, a health unit was chosen to be part of the study scenario. In Almenara, which is considered the hub of this micro-region, data were collected at two Primary Health Care units and the Secondary Health Care service (Medical Specialty Center) was also included, which is a municipal referral center for leprosy care. In total, the researchers visited ten Primary Health Care units, all of which authorized within the FHS, and one referral center, located in the city of Almenara.

Semistructured interviews and document research in institutional and statistical records were used as data collection techniques. To achieve the representativeness of services and subjects, with a view to a closer look at the research problem, in total, 45 interviews were held. Those subjects who were most representative regarding health practices in leprosy in the social group under study were invited, as indicated by municipal managers. In each city, at least one physician, one nurse and one community health agent were invited, besides the health managers. As the latter category includes Municipal Health Secretaries, Primary Health Care Coordinators and Coordinators of the Municipal Technical Area in Leprosy, the number of interviewees varied among cities due to the presence of this respective professional and his/ her availability. In some cities, however, more than one subject was interviewed per professional category, due to their relevance as social actors in the accomplishment of leprosy control actions, fundamental to apprehend 
the empirical reality. The study subjects included 13 Managers; ten Physicians; twelve Nurses and ten Community Health Agents. In the document research, 111 Proceedings of the Municipal Health Council were analyzed (between 2005 and 2007); 10 Municipal Health Plans (the last two plans identified, with periods varying among the cities) and 11 End Reports of Municipal Health Conferences (the last two reports identified, with periods varying among the cities). Data were collected between November 2007 and February 2008.

For data treatment and analysis, Thematic Content Analysis according to Bardin was used(12). In practice, data analysis comprised the following steps: complete transcription of the interviews and arrangement of the document material; coding of the interviews and documents; floating reading of gross data; coding of gross data in record and context data; establishment of empirical categories and interpretation of empirical data in relation to analytic categories. The following identifications were used for the interviewees, followed by a number in rising order, according to the number of interviewees per category: Managers: $M_{1} ; M_{2} ;$ up to $\mathrm{G}_{13}$; Physicians: $\mathrm{P}_{1} ; \mathrm{P}_{2}$ up to $\mathrm{P}_{10}$; Nurses: $\mathrm{NUR}_{1}$; $\mathrm{NUR}_{2}$; up to $\mathrm{NUR}_{12}$; Community Health Agents: $\mathrm{CHA}_{1} ; \mathrm{CHA}_{2}$ up to $\mathrm{CHA}_{10}$.

This study complies with National Health Council Resolution 196/96, which establishes guidelines and regulations for research involving Human Beings. Approval was obtained from the Institutional Review Board at the Federal University of Minas Gerais, opinion No ETIC 459/05 - Ad 01/07. Funding for the research was obtained from the National Council for Scientific and Technological Development (CNPq), through Call MCTCNPq/MS-SCTIE-DECIT-N.35/2005.

\section{Results and Discussion}

In the Almenara micro-region, leprosy is endemic and constitutes a Public Health problem. The spatial distribution analysis of leprosy cases in the Almenara micro-region notified between 1998 and 2006 identified the presence of two clusters, one cluster with cases above expected levels, which includes Jacinto and parts of Almenara, Jequitinhonha, Rubim and Santo Antônio do Jacinto and Santa Maria do Salto, and another cluster with cases below expected levels, including Monte Formoso and parts of Joaíma and Jequitinhonha(6). These authors suggest that a relation exists between the strength of disease transmission and the organization of health services( ${ }^{(6)}$. Jequitinhonha has several FHP's [Family
Health Program], there seem to be seven FHP's and four or five physicians, nurses, trained in leprosy, right? That is, the city has trained staff to do it, but these people are trained and do not diagnose in practice, you know? $\left(\mathrm{M}_{13}\right)$. A professional from a hyperendemic city even establishes the following relation: Isn't the region endemic? Don't cases exist? Where there are no cases, it's not because they do not exist, it's because the diagnosis is not being reached, the reasoning is logical, you see? $\left(\mathrm{P}_{10}\right)$.

Thus, it can be inferred that cities in the "above expected" cluster have more efficient health services in terms of LCA. The configuration of care or intervention models in a population's health needs depends on the historical context and on the combination of technologies that organize the work means (knowledge and instruments) used in health practices ${ }^{(13)}$.

As the decentralization process of LCA occurred distinctly according to the place and moment in history, in the Almenara micro-region, there are cities that are more advances, others intermediary and others that still are very diffident $\left(\mathrm{M}_{13}\right)$.

Based on this classification by one manager, Jacinto, Jordânia, Santa Maria do Salto, Palmópolis and Rubim can be considered part of the group of "advanced cities". In all of these cities, leprosy care has been decentralized to FHS units and FHS coverage rates in all cities amount to $100.0 \%$ of the urban and rural population. To plan this decentralization, the cities received support from the Regional Health Management (RHM) in Pedra Azul, which trained the physicians and nurses, as generalist health professionals perform prevention and control actions at a leprosy service integrated into Primary Health Care ${ }^{(14)}$. This training represented the starting point for decentralization.

The first city where leprosy care actions were decentralized in the Primary Health Care network was Rubim, in 2005. In 2006, the other cities started the decentralization process. One important characteristic of this decentralization process was that, in these cities, except for Palmópolis, a referral team was maintained to support the FHS teams: later, when the FHP's came and the staff was trained, it became easier for us. So, all FHP professionals today, they took the course, they took the training about control actions. So all FHP physicians diagnose and we accompany them and meet every Friday afternoon, we meet when there is a case, right? $\left(\mathrm{NUR}_{5}\right)$. To support Leprosy control activities in a care model integrated into Primary Care actions, it is recommended that a referral unit be available to support and supervise the Primary Care teams, conducting cases with complications for example $\mathrm{e}^{(14-15)}$. 
Case discussions with more experienced professionals are not only a staff training activity, but also an opportunity to improve the leprosy work quality ${ }^{(11)}$. This supports the fact that the epidemiological behavior of leprosy is influenced by health service quality when control programs are put in practice, as leprosy prevalence and detection rates are strongly influenced by health services operating capacity ${ }^{(16)}$.

And the organization of health services, especially of the leprosy prevention and control program, was responsible for the increase in cases numbers in Jacinto. The Minas Gerais State Secretary of Health even considered the city a priority for disease control in the Vale do Jequitinhonha. Primarily, health professionals' awareness was raised during a course on leprosy prevention and control actions, held in Almenara in 2005. These professionals "waved the flag", followed the course orientations, organized the health services and decentralized leprosy care to the FHS units: each FHP performed its actions independently, it was not an organized thing with a flow, that didn't exist, it was independent, each went there, diagnosed, treated etc., it was not organized, no, it was isolated, each unit performed its isolated actions $\left(\mathrm{M}_{9}\right)$.

But this decentralization occurred at random, without supervision, which is why each primary health care unit performed leprosy actions separately. In 2007, Jacinto started the organization process of leprosy care decentralization. First, all health professionals with a higher education degree (including dentists) were trained, followed by training for Community Health Agents (CHA), nursing auxiliaries and technicians, professionals from the National Health Foundation (FUNASA), cleaning professionals and Basic and Secondary education teachers. After all professionals were sensitized, the city started to mobilize the community. Several strategies were used, such as: radio interviews, lectures on leprosy in hypertension and diabetes groups, distribution of pamphlets and orientations by CHA's during home visits.

This city adopted a supervision policy of leprosy control actions performed by Primary Health Care professionals(17), as decentralization means that the FHP goes for it, except that the FHP doesn't go for it without stimulus $\left(\mathrm{P}_{10}\right)$, a municipal reference team was created for leprosy, which supports the FHS professionals: there was no need to create a specialty center, none of that, it was the FHP, it's just that then, later, I will call that patient once, meet with him, also perform a complete assessment of esthesiometry, visual acuity, everything. Not like: let's check! Everyone knows practically the same thing about leprosy, but like this: as these professionals may have dealt less with leprosy, it's a matter of training, nerve palpation is something difficult, they thought it was thicker, I didn't find it. So we are doing kind of centralized, a bit like being a tutor, being a bit of a reference, but the units are responsible for the work $\left(P_{10}\right)$. The success formula of Jacinto's leprosy control program was based on a mixed model, which is neither centralized nor decentralized. This model rests on four pillars: sensitized and committed professionals attentive eyes, constant surveillance $\left(\mathrm{P}_{10}\right)$, integrated FHS teams, a mobilized community and working for results.

Flaws in the support pillars of the leprosy program characterize the health services in the cities belonging to the "below expected cases" cluster: Monte Formoso and Jequitinhonha. Jequitinhonha is a large city, with trained professionals, but who do not find the cases either. One, two cases appear per year and those are level II cases. So we see a hidden prevalence in the city, it's a city that does not take off either $\left(\mathrm{M}_{13}\right)$. The proportion of disabilities about new cases indicates health services' passiveness in putting in practice control strategies and appoints the need to intensify actions, mainly community awareness-raising and professional training, so as to promote early diagnosis and treatment for all cases in the community(18).

Managers and professionals' own discourse confirms that these cities are not prepared to deal with leprosy: there's no structured work, no, we don't have that, it's what I told you, we work with spontaneous demand here. The case arrived, the suspicion, we provide it, we try to clarify the diagnosis as all of our cases here resulted from spontaneous demand, that is, we don't have that search for the problem. And the leprosy program mainly recommends that search, that search for these patients who are not discovered, right? And we don't have that program here, no. And I confess, there's no monitoring, there's no integrated leprosy service, no, not even at our unit, nor in the region $\left(\mathrm{P}_{3}\right)$.

The professionals working in Jequitinhonha and Monte Formoso appoint that neither health service organization nor professional training exists to perform LCA. In these situations, questions are raised on the disease's true epidemiological situation(19), mainly in Monte Formoso, a city that has never diagnosed one case of the disease in its community ${ }^{(6)}$.

In the cities manager 13 considered "intermediary" in leprosy control, i.e. Salto da Divisa and Almenara, despite flaws in the organization of the leprosy program, the professionals are diagnosing the cases, but in more advanced clinical forms, with already established physical disabilities(20). Early case diagnosis is essential for successful control of the disease and its complications ${ }^{(21)}$. In Salto da Divisa, none of the cases 
was diagnosed in the indeterminate form, which is the initial form of the disease(20). In that city, professionals are trained, leprosy care is decentralized to the FHS units, but no integration exists among the teams, and professionals from the same team even face difficulties to program activities at the unit. Another aggravating factor is that professionals have not disseminated the signs and symptoms of the disease to the community yet. The population's lack of knowledge is one of the factors impeding early diagnoses. Salto da Divisa is a city of which we know that cases exist, but where the service has not taken off, has not sought these cases and we see a very diffident spontaneous demand, due to a lack of dissemination campaigns about signs and symptom. No active search has been done really $\left(\mathrm{M}_{13}\right)$.

In Almenara, until 2005, leprosy care was fully centralized at the Medical Specialty Center and this centralization was responsible for Primary Health Care professionals' lack of interest in the disease. In 2005, the Municipal Health Secretary decided to decentralize LCA and faced various obstacles during this process, such as physicians' refusal to deliver this type of care at the Primary Health Care level. Therefore, further training was necessary to make professionals feel capable of assuming the new responsibilities, thus permitting the implantation of LCA in Primary Health Care.

Investments in professional training and in community education campaigns were reflected in an increase in the number of cases diagnosed in 2005 (57 new cases) in comparison with the year before (47 cases diagnosed in 2004)(20). These are the expected results when health professionals are adequately trained, as they become capable of diagnosis and treatment in Primary Health Care ${ }^{(14)}$. In Almenara, however, cases are still found that could be solved at the FHP units, but are forwarded to the referral center due to a lack of medical preparation: some cases appear here which several physicians saw and did not diagnose. Sometimes the spots are very characteristic, the patient is complaining of lack of sensitivity and, sometimes, it seems that there was not really that interest, nobody really asked, examined correctly, you know? In some cases, the patient actually came here with a sequel, with that claw hand, you know? Or that foot without sensitivity and that was not diagnosed at the units. The physicians from the family health units saw the case, but it was not diagnosed $\left(\mathrm{NUR}_{12}\right)$.

In the city of Almenara, what hampered the stronger decentralization of leprosy control actions was the resistance of the referral center physician, who opposed the decentralization out of fear of how clients would be monitored at the primary health care unit, out of fear that clients would evolve to a reaction episode and that professionals would not be able to handle the case. "The factors that have hampered this integration are, among others: [...] the old school view that specialized centers are responsible for control of this disease instead of Primary Health Care; the referral service's difficulty to understand and incorporate its new role of transmitting experience and supporting Primary Health Care, instead of fully taking charge of treatment; health professionals' education, oriented towards specialization, as well as the lack of updated information on leprosy, preserving the prejudice against patients among health professionals"(9).

The referral unit in Almenara is also responsible for care delivery to those $35.0 \%$ of the population not affiliated with the FHS. The remainder of the population receives care at primary health care units and the main challenge the city of Almenara faces is to guarantee access to high-quality LCA at FHS units: there are seven primary care units today who also perform leprosy work, some of which are more developed, while others do not display the performance we expected in the decentralization process. The referral center attends, cases are referred by all other primary care units, family health units, the community health agents program, which are not able to solve the case, which are not able to reach the diagnosis, doubts are forwarded her to the referral center, besides all those other cases not covered by Primary Health Care, you see? $\left(\mathrm{M}_{11}\right)$.

Thus, Almenara has two leprosy care models: one decentralized model, which attends to the population covered by FHS actions which, despite difficulties, have a broader conception of the leprosy work process, involving disease prevention and control actions; and a centralized model, practiced at the Medical Specialty Center, a municipal referral unit for leprosy, responsible for care delivery to that $35.0 \%$ of the population not affiliated with the FHS, where fragmented actions of the leprosy program are practiced.

The maintenance of the vertical leprosy care model does not enhance the population's access to diagnosis and treatment in the initial phase of the disease. It also hampers active search, contact search, educative actions, as the reference center does not have professionals to perform these activities, contributing to the existence of a hidden prevalence in these regions without FHS teams. These are examples of limitations that make leprosy programs integrated in Primary Health Care more appropriate to strengthen disease control activities in comparison with vertical programs(22). Therefore, there is no more room for specialists to deliver leprosy care, 
which is why FHS teams have to assume the commitment to perform LCA.

The actual decentralization of LCA will take place when the city reaches $100.0 \%$ of the population covered by the FHS and, when this is the case, the leprosy control program will be much more structured and strengthened. FHS units will be responsible for active search, awareness-raising campaigns in the community, diagnosis, treatment, disability prevention and contact investigation. In this model, early case diagnosis is expected, in paucibacillary clinical forms, diagnosed without physical disabilities, high coverage rates for contact investigation and low proportion of treatment abandonment. And the referral unit will be responsible for attending those cases in which FHS units do not manage to confirm the diagnosis, delivering care to clients going through reaction episodes, offering rehabilitation services and permanent education of municipal professionals.

\section{Final considerations}

The integration of leprosy prevention and control actions into Primary Health Care is the best strategy to achieve disease control in endemic areas, as this process rests on the principles of equity and accessibility.

Thus, diagnosis and treatment activities happen close to the community and are offered together with other programs health services accomplish, available during health unit work hours, so that this disease does not require services offered by referral centers.

The decentralization process of leprosy control actions in Primary Health Care in the Almenara microregion started late (in 2005), when the disease elimination target was postponed to 2010 and, since then, has been considered a strategy able to face endemic leprosy in the Almenara micro-region. Therefore, in some cities, the decentralization process to FHS units remains incomplete as, in some units, only suspected diagnoses are reached, while the referral unit is left in charge of treatment. One historical characteristic of Almenara is leprosy care at the Medical Specialty Center (referral unit for leprosy), placing FHS professionals between the new and former care model, in a contradictory process that ends up not permitting Primary Health Care's effective involvement in disease control. Managers should acknowledge this obstacle in order to face and overcome the problems, with a view to supporting the decentralization process of LCA in primary health care.

The main challenge cities in this study face is the restructuring of the disease control program, based on effective public policies that can guarantee leprosy control in primary health care, thus reasserting the potential of the FHS in the reorientation of the care model.

\section{References}

1. World Health Organization. Weekly Epidemiol Record 2009;84(33):333-40.

2. Lapa T, Ximenes R, Silva NN, Souza W, Albuquerque MFM, Campozana G. Vigilância da hanseníase em Olinda, Brasil, utilizando técnicas de análise espacial. Cad Saúde Pública. 2001;17(5):1153-62.

3. Gauy JS, Hino P, Santos CB. Distribuição espacial dos casos de hanseníase no município de Ribeirão Preto no ano de 2004. Rev. Latino-Am. Enfermagem. 2007;15 (3):460-5.

4. Lana FCF, Amaral EP, Franco MS, Lanza FM. Detecção da hanseníase no Vale do Jequitinhonha Minas Gerais: redução da tendência epidemiológica ou problemas operacionais para o diagnóstico? Hansen Int. 2004;29(2):118-23.

5. Secretaria de Estado da Saúde (BR). Coordenadoria de Controle da Hanseníase. Seminário Estadual 2009. Belo Horizonte (MG); 2009.

6. Amaral EP, Lana FCF. Análise espacial da hanseníase na microrregião de Almenara, MG, Brasil. Rev Bras Enferm. 2008;61(especial):701-7.

7. Organização Mundial de Saúde. Estratégia global para aliviar a carga da hanseníase e manter as atividades de controle da hanseníase (Período do Plano: 2006-2010). Genebra; 2005.

8. Conselho Nacional de Secretários de Saúde (BR). Sistema Único de Saúde. Brasília (DF): CONASS; 2007. 9. Grossi MAF. Vigilância da Hanseníase no Estado de Minas Gerais. Rev Bras Enferm. 2008;61(especial):781. 10. Kasturiaratchi ND, Settinayake S, Grewal P. Processes and challenges: how the Sri Lankan health system managed the integration of leprosy services. Lepr Rev. 2002; 73 (2):177-85.

11. Mendes-Gonçalves RBM. Tecnologia e organização social das práticas de saúde: características tecnológicas do processo de trabalho na rede estadual de centros de saúde de São Paulo. São Paulo: HUCITEC; 1994. 278 p. 12. Bardin L. Análise de conteúdo. Lisboa: Edições 70; 1977. $229 \mathrm{p}$.

13. Paim JS. Modelos assistenciais: reformulando o pensamento e incorporando a proteção e a promoção da saúde. [acesso em: 06 dez 2008]. Disponível: http:// www.anvisa.gov.br/Institucional/snvs/coprh/seminario/ modelo.htm 
14. Visschedijk J, Engelhard A, Lever P, Grossi MAF, Feenstra P. Leprosy control strategies and the integration of health services: an international perspective. Cad Saúde Pública. 2003;19(6):1567-81.

15. Samy AA. National Workshop on "Is integration a leap forward? - Implications of integration on quality care in leprosy", Mumbai. Lepr Rev. 2007;78(3):306-8. 16. Waldman EA, Silva LJ, Monteiro CA. Trajetória das doenças infecciosas: da eliminação da poliomielite à reintrodução da cólera. Inf. Epidemiol. SUS. 1999; 8(3):5-47.

17. Moreira TMA. Avaliação da descentralização das ações programáticas de hanseníase: um estudo de caso [tese]. Rio de Janeiro: Escola Nacional de Saúde Pública, Fundação Oswaldo Cruz; 2002.

18. Lana FCF, Amaral, EP, Lanza, FM, Saldanha ANSL. Desenvolvimento de incapacidades físicas decorrentes da hanseníase no Vale do Jequitinhonha, MG. Rev. Latino-Am. Enfermagem. 2008;16(6):993-7.

19. Helene LMF, Pedrazzani ES, Martins CL, Vieira CSCA, Pereira AJ. Organização de serviços de saúde na eliminação da hanseníase em municípios do Estado de São Paulo. Rev Bras Enferm. 2008;61(especial):744-52.

20. Amaral EP. Análise espacial da hanseníase na microrregião de Almenara - Minas Gerais: relações entre a situação epidemiológica e as condições socioeconômicas [dissertação]. Belo Horizonte: Escola de Enfermagem da Universidade Federal de Minas Gerais; 2008.

21. Byamungu DC, Ogbeiwi OI. Integrating leprosy control into general health service in a war situation: the level after 5 years in Eastern Congo. Lepr Rev. $2003 ; 74(1): 68-78$.

22. Feenstra P, Visschedijk J. Leprosy control through general health services - revisiting the concept of integration. Lepr Rev. 2002;73(2):111-22. 